\title{
The Effect Multiple Role Conflicts and Emotional Intelligence: Analysis of Nunukan District Women Nurses' Performance
}

\author{
Andre Suandi Simbolon ${ }^{1}$, Shalahuddin ${ }^{2}$, Ahmatang $^{3}$, Erick Karunia ${ }^{4}$ \\ Faculty of economics - Universitas Terbuka ${ }^{1}$, \\ Faculty of economics - Universitas Borneo Tarakan ${ }^{2,3,4}$ \\ $\left\{\right.$ sha@borneo.ac.id $\left.{ }^{2}\right\}$
}

\begin{abstract}
This study aims to find out the effect of multiple role conflicts and emotional intelligence on performance interests. This research uses quantitative approach with survey method. The sampling method used is non-probability sampling with sampling technique using purposive sampling. The sample in this study was Female Nurses of Nunukan District General Hospital with a total sample of 102 respondents. The analysis method used is regression analysis with the help of SPSS program version 25. The results of this study showed that variable double role conflict negatively affects the performance of female nurses and variable emotional intelligence positively affects the performance of female nurses.
\end{abstract}

Keywords: Dual Role Conflict; Emotional Intelligence; Performance

\section{Introduction}

Entering the current digitalization problem, which is demonstrated by the development of science and technology in various fields that have been increasingly advanced and rapidly, poses many new challenges that must be faced by each organization [1]. Please note that in carrying out work, there are many factors that can affect the quality and quantity of an employee's work, such as multiple role conflicts, especially those experienced by female nurses. Acting as a worker and as a housewife are two roles that are not easy. [2] stated that the difficulty in fulfilling the often conflicting guidance of work and family can lead to family-employment conflicts. The dual roles experienced by women in the family, the slowest women also played a role in her career. This makes it difficult for a female employee to balance the two roles.

Good emotional intelligence from an employee will be able to overcome challenges, as well as make a productive and responsible person in solving problems related to the tasks and obligations that have been given by the organization. Patton in [3]. Employees who have high emotional intelligence, will be able to create a balance of themselves and their environment, and able to work with colleagues and fellow friends who have different backgrounds. The more complex a job is, the more important emotional intelligence is required. In the world of work there are social interactions where an employee must be capable in handling himself or others, 
so as to encourage an employee to achieve further success in order to achieve good performance.

Employee performance is a matter of quality, quantity and productivity of work in accordance with the duties and obligations that have been given by the organization [4]. Good employee performance always contributes positively to the organization, if the performance itself has a negative impact then there needs to be an evaluation so that the problem can be fixed [5]. Organizations also generally want to make progress so that there is a favorable reciprocity. Therefore, it is expected that every organization in each region / city has a reliable employee quality in supporting economic growth.

Some differences from previous research that have been done about the influence of multiple role conflicts and emotional intelligence on employee performance make these variables very interesting to research. [6], Stated that the conflict of dual roles and emotional intelligence positively affects the performance of married female nurses at the General Hospital Dr. Adjidarmo Rangkasbitung Lebak - Banten, on the contrary from research [7], stated that emotional intelligence and double role conflict have a negative impact on performance in female lecturers at Diponerogo University, Semarang.

This paper aims to prove the influence of dual role conflict and emotional intelligence on the performance of female nurses in Nunukan District. By looking for data and information that has been collected so that research results are obtained.

\section{Methodology}

This Method is to get a scientific way to achieve the goals for which its usefulness has been determined. [8]. This research will use survey method with quantitative approach. Primary data collection method using oral and written statements [9]. The research time will be conducted in February until March 2020.

Samples from this research use non-probability techniques with purposive sampling method conducted by taking samples from the population based on a predetermined criterion based on judgment and certain conditions (quota) certain [10]. In this study, the sample to be studied has criteria (1) Female nurse of Nunukan District General Hospital, (2) has been married and or already has children. The number of samples used in this study as many as 102 respondents. Data collection techniques are done by giving a set of questions and statements in writing to respondents to be answered. The Likert scale is used to measure the attitudes, opinions and perceptions of a person or group of people about social phenomena [8].

The test used in this study is using multiple regression analysis techniques. This analysis is also used to determine whether or not the influence of dual role conflicts and emotional intelligence is affected by the performance of employees, [11]. As for determining each independent variable partially affects dependent variables using t test, and can be obtained in a count of SPSS output results while t-table obtained from statistics by looking at the value of significance and degree of freedom.

In table 1 , it can be seen that the highest percentage in this study was respondents with DIII education level of $68.6 \%$ or as many as 70 respondents. While the lowest percentage is found in respondents with a high school education level of $10.8 \%$ or 11 respondents. based on the high working period of respondents 3 to 6 years with a percentage of $56.9 \%$ or about 58 respondents. And for the highest age of respondents 17 to 25 years with presentence that is $46.1 \%$ or 47 respondents. 
Table 1. Descriptive Respondents

\begin{tabular}{clc}
\hline No & Characteristics of respondents & Percentage (\%) \\
\hline 1 & Education level: & \\
& High School/Equivalent & $10,8 \%$ \\
& DIII & $68,6 \%$ \\
& S1 & $20,6 \%$ \\
2 & Working Period: & \\
& < 3 Years & $21,6 \%$ \\
& 3-6 Years & $56.9 \%$ \\
& > 6 Years & $21,6 \%$ \\
Age: & \\
& 17-25 Years & $46,1 \%$ \\
& 26-35 Years & $45,1 \%$ \\
& 35 Year and above & $8,8, \%$ \\
\hline
\end{tabular}

Source : Primary Data Processed, 2020

\section{Operational Definitions}

\subsection{Dual Role Conflicts}

Dual role conflicts are two forms of female roles, namely those that act as housewives and also as career women. Research conducted by Howard and Donofrio in [12] using indicators using the Likert scale 1-5. The indicators presented include: (a) I think it is burdened with the pressure of labor that is given. (b) I think the demands of the task are too much and not in accordance with the capacity. (c) I feel the work makes for a lack of intensity in my time with family. (d) Overcrowded work made me miss opportunities and time to do other activities. (e) I often have a choice conflict between carrying out work tasks or meeting family needs.

\subsection{Emotional Intelligence}

Emotional intelligence is a way of controlling the squeeze for yourself as well as to get to know others, motivate yourself and the ability to manage emotions well in yourself to connect with others. [13], using indicators using the Likert 1-5 scale. The indicators presented include (a) I know what I don't and can do. (b) When I am angry and panicked, I can still calm down. (c) I always consider the feelings of others when I resolve conflicts. (d) When it comes to giving my opinion, it is sometimes selfish. (e) When I'm stressed sometimes, I do positive things. (f) When I'm having a failure, I'm not desperate. (g) I can feel what others are doing. (h) I am open with others regarding the issue of my condition. (i) I can reconcile conflicts between colleagues. (j) I am able to be a good listener to complain.

\subsection{Performance}

Performance is the result of work that can be achieved by a person or group of people in the organizational environment, in accordance with the authority and responsibility held by each, to achieve the goals of the organization by not violating the established regulations, in accordance with moral and ethical requirements. according to Bernadin in [14], using the Likert scale indicator 1-5. Indicators include: (a) I have quality according to established work standards. (b) I am able to carry out the task given quickly and efficiently. (c) I am able to complete tasks in a 
timely manner. (d) I am able to do the job to the end by making the most of my resources. (e) I am able to work on my own without the intervention of others. (f) The work I do is full of responsibility and commitment.

\section{Result and Discussion}

\subsection{Validity and Reliability Test}

Validity tests are used to measure whether or not a questionnaire is valid, a questionnaire is said to be valid if the question on the questionnaire is able to reveal something that will be measured by the questionnaire. Reliability Test is a measure of stability and consistency of respondents in answering matters related to question constructs that are the dimensions of a variable and compiled in a form of questionnaire. Measurement with the CRONBACH Alpha statistical test SPPS tool (a). A variable is said to be reliable if it provides a cronbach value of Alpha $>0.60$.

\begin{tabular}{|c|c|c|c|c|c|}
\hline Variable & Major Item & $\begin{array}{c}\text { Value Pearson } \\
\text { Correlation } \\
\text { (r-count) }\end{array}$ & $\begin{array}{l}\text { r-Table } \\
\text { value }\end{array}$ & $\begin{array}{l}\text { Cronbach's } \\
\text { alpha }\end{array}$ & Desc. \\
\hline \multirow[t]{5}{*}{ Dual Role Conflicts } & KPG.1 & 0,499 & 0,1946 & \multirow{5}{*}{0,704} & \multirow{5}{*}{$\begin{array}{l}\text { Valid and } \\
\text { Reliable }\end{array}$} \\
\hline & KPG.2 & 0,564 & & & \\
\hline & KPG.3 & 0,556 & & & \\
\hline & KPG.4 & 0,660 & & & \\
\hline & KPG.5 & 0,483 & & & \\
\hline Emotional & KE.1 & 0,826 & & \multirow{10}{*}{0,679} & \multirow{10}{*}{$\begin{array}{l}\text { Valid and } \\
\text { Reliable }\end{array}$} \\
\hline \multirow[t]{9}{*}{ Intelligence } & KE.2 & 0,854 & 0,1946 & & \\
\hline & KE.3 & 0,728 & & & \\
\hline & KE.4 & 0,661 & & & \\
\hline & KE.5 & 0,833 & & & \\
\hline & KE.6 & 0,623 & & & \\
\hline & KE.7 & 0,462 & & & \\
\hline & KE.8 & 0,259 & & & \\
\hline & KE.9 & 0,578 & & & \\
\hline & KE.10 & 0,433 & & & \\
\hline \multirow[t]{6}{*}{ Performance } & K.1 & 0,446 & 0,1946 & \multirow{6}{*}{0,674} & \multirow{6}{*}{$\begin{array}{l}\text { Valid and } \\
\text { Reliable }\end{array}$} \\
\hline & K.2 & 0,419 & & & \\
\hline & K.3 & 0,547 & & & \\
\hline & K.4 & 0,528 & & & \\
\hline & K.5 & 0,552 & & & \\
\hline & K.6 & 0,474 & & & \\
\hline
\end{tabular}

\subsection{Normality Test Results}

The normality test aims to test whether in the regression model, disruptive or residual variables have a normal distribution. As it is known that the normality test assumes that residual values follow the normal distribution or not conducted statistical tests Kolmogorov-Smirnov Test. Residual distributed normal if it has a significance value of $>0.05$, The results of normality test can be seen in the following table: 
Table 3. Normality Test Results One-Sample Kolmogorov-Smirnov Test

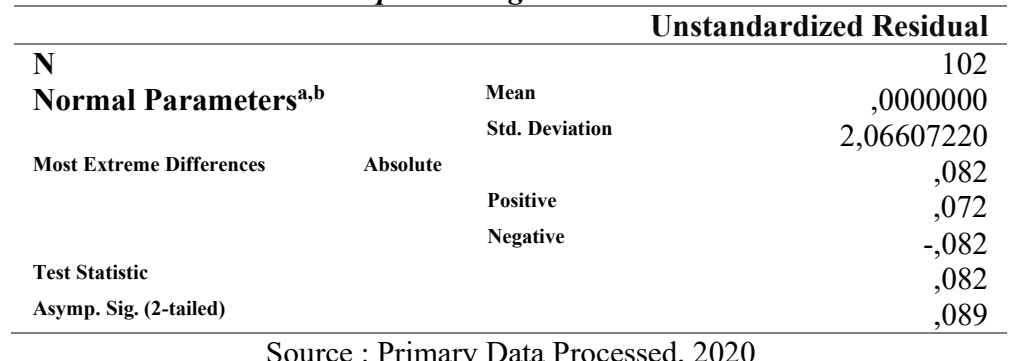

Source : Primary Data Processed, 2020

\subsection{Multicolinearity Test Results}

The multicolinearity test tested whether the regression model was found to be inter-variebel-free (independent). A good regression model should not be correlated between independent variables. Multicority can also be seen from the value of tolerannce and variance inflition factor (VIF). The cutof value commonly used to indicate multicolonirity is the tolernce value $>10$. Multicoliearity test results can be shown in the following table:

Table 4. Multicolinearity Test Results

\begin{tabular}{ccc}
\hline Variabel & $\begin{array}{c}\text { Collinearity } \\
\text { Tolerance }\end{array}$ & $\begin{array}{c}\text { Statistics } \\
\text { VIF }\end{array}$ \\
\hline Dual Role Conflicts & 0,998 & 1,002 \\
Emotional Intelligence & 0,998 & 1,002 \\
\hline \multicolumn{2}{c}{ Source : Primary Data Processed, 2020 }
\end{tabular}

In tebel 4.1 shows that no independent variable has a tolerance $>10$. Vif calculation results also show independent variables have a VIF of $<10$. Based on the coefficient in the table, it is known that the VIF value is 1,002 (KPG Variable) and (VARIABLE KE). It can therefore be concluded that the indepnden variable is free from the classic assumption of multicolinearity because the VIF result is less than 10.

\subsection{Heterokedastisity Test Results}

Heterokedastisity test is a regression model that does not occur varience inequality from residual from one observation to another. If the varience from residual one observation to another is not fixed, then it is suspected that there is a problem of heterokedastisitas. It can be known the absence of heterokedastisity in this study used scattler plot diagrams. If the data is located spread around a diagonal line then it can be said that there is no heterokedastisity but homokedastisitas. Heterokedastisitas results can be shown in the following figure: 


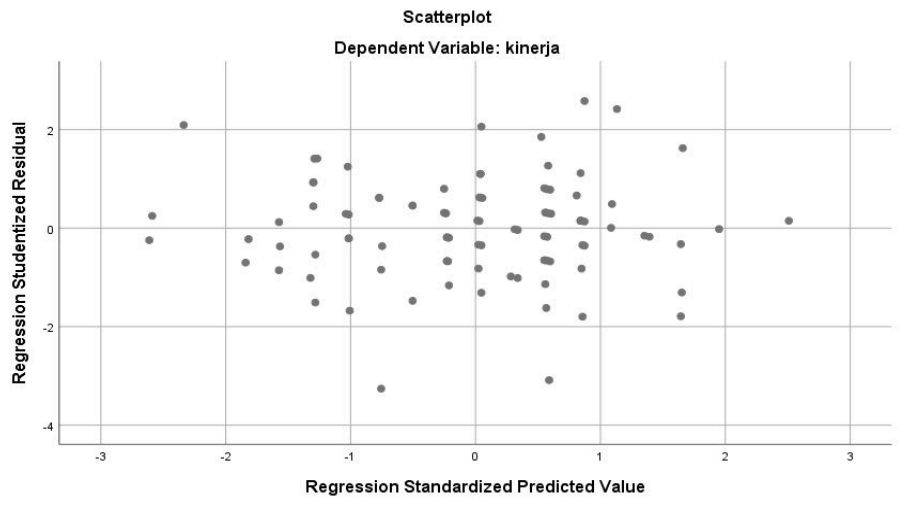

Source: Primary Data Processed, 2020

Fig. 1. Heterokedastisitas Test Results

From figure 1 seen from the points scattered randomly and scattered both above and below the number 0 on the $\mathrm{Y}$ axis, there is no specific pattern that is organized. It can therefore be concluded that there is no heterokedastisitas in this regression model.

\subsection{Multiple Linear Regression Analysis}

Multiple regression analysis is used to determine the magnitude of the variable effect of Dual Role Conflict and Emotional Intelligence on Performance. the results of multiple regression analysis as follows be interpreted that dual role conflicts negatively affect performance in order to conclude that hypothesis 1 is supported.

Table 5. Results of Multiple Linear Regression Analysis

\begin{tabular}{|c|c|c|c|c|c|c|}
\hline \multicolumn{3}{|c|}{ Influence } & $\beta$ & t-count & Sig & Description \\
\hline (con & ant) & & 10,843 & 4,274 & 0,000 & \\
\hline Dual Role Conflicts & $\rightarrow$ & Performance & $-0,010$ & $-0,106$ & 0,916 & Accepted \\
\hline Emotional Intelligence & $\longrightarrow$ & Performance & 0,325 & 5,858 & 0,000 & Accepted \\
\hline
\end{tabular}

Effect of Dual Role Conflict on Performance In table 4 shows that the t-count value of -0.106 is significant $\alpha=0.05$ (one tailed) $t$-table value of 1.9840 , therefore the $t$-count value $<$ $\mathrm{t}$-table and a significant value of 0.916 greater than 0.05 . Based on these results, it can

From the data of female nurse respondents Nunukan District Hospital has an average age of 25 to 35 years, diii education background with a working period of 3 to 6 years. Dual role conflk can arise because the work is mixed by the affairs of the amount of time devoted to carrying out the work to prevent a person from carrying out his obligations at home, resulting in conflicts that will affect the performance of the workplace. Dual role conflicts in workers who are married and or already have children can be defined as a form of role conflict where the guidance of the role of employment is less fulfilled. At the same time, one tries to fight the demands of another role so that it can be said that conflicting roles have an influence on performance. This is supported by several details of questionnaire statements filled out by respondents nurse women nunukan district general hospital on average agreed on the variable conflict dual role stated (1). I felt burdened with the pressures of the work given and (5). I often have conflicts of choice between carrying out work tasks or meeting family needs. 
Emotional Intelligence to Performance In table 4. indicates that the relationship has a t-count value of 5,858 significant at $\alpha=0.05$ (one tailed) t-table value of 1.9840 , therefore $t$-count $>$ t-table and a significant value of 0.000 smaller than 0.05 . Based on these results it can be interpreted that emotional intelligence has a positive and significant effect on performance, thus it can be concluded that hypothesis 2 is accepted.

From the data of female nurse respondents in Nunukan District, the average productive age is between 25 to 35 years, the background of DIII education with a working period of 3 to 6 years. The improved performance is influenced by the high level of emotional intelligence that nurses have. This is because, self-awareness that is good for nurses will tend to be in accordance with organizational standards, so that eventually it will achieve better kinrja. This is supported by several details of questionnaire statements filled out by respondents nurse women nunukan district general hospital on average that is about the variables of emotional intelligence stated (3). I always consider other people's feelings when I resolve conflicts at work and (9). I can reconcile the conflicts that occur between my coworkers.

\section{Conclusion}

Based on the results of research conducted on female nurses in Nunukan District, shows that the average respondent has different perceptions. This research shows that dual role conflicts negatively affect the performance of nurses, which means that the higher the dual role conflicts experienced by female nurses, the lower the level of employee performance. Furthermore, emotional intelligence has a negative and significant effect on the performance of female nurses, which means that the better the emotional intelligence of female nurses, the better the performance.

\section{References}

[1] M. A. Putri, "Pengaruh Iklim Organisasi Dan Lingkungan Kerja Fisik Terhadap Kinerja Karyawan PDAM Way Rilau Kota Bandar Lampung,” 2019.

[2] A. G. Bedeian and A. A. Armenakis, "The cesspool syndrome: How dreck floats to the top of declining organizations," Acad. Manag. Exec., 1998, doi: 10.5465/ame.1998.254978.

[3] R. Setianigrum, "Pengaruh kecerdasan emosional terhadap kinerja (studi pada karyawan PT.Jasa Raharja Cabang Jawa Timur," Universitas Brawijaya Malang, 2016.

[4] Z. W. Itsalis, A. Prasetya, and I. Ruhana, "Pengaruh Program Keselamatan dan Kesehatan Kerja Terhadap Motivasi Kerja dan Kinerja Karyawan (Studi Pada Karyawan Bagian Produksi PT. Citra Gading Asritama Di Proyek Mall Dinoyo City Malang, Jawa Timur)," J. Adm. Bisnis, vol. 41, no. 1, pp. 108-117, 2016.

[5] A. A. A. P. Mangkunegara, Evaluasi kinerja SDM. Tiga Serangkai, 2005.

[6] K. Dipayanti and I. R. Pertiwi, "Pengaruh Konflik dan Kecerdasan Emosional Terhadap Kinerja Perawat Wanita yang sudah menikah pada RSUD dr. Adjidarmo Rangkasbitung," Inovasi, vol. 6, no. 1, pp. 29-49, 2019.

[7] F. Al Shofa and I. F. Kristiana, "Kecerdasan emosi dan konflik peran ganda pada dosen wanita di Universitas Diponegoro," Empati, vol. 4, no. 4, pp. 150-155, 2015.

[8] Sugiyono, Metode penelitian pendidikan:(pendekatan kuantitatif, kualitatif dan $R \& D)$. Alfabeta, 2008. 
[9] E. M. Sangadji and Sopiah., Metodologi penelitian: pendekatan praktis dalam penelitian. 2010.

[10] B. Hartono, "Pengaruh Komitmen Organisasional Terhadap Kepuasan Kerja Karyawan Paparonâs Pizza City of Tomorrow," Agora, 2013.

[11] I. Ghozali, Aplikasi analisis multivariate dengan program SPSS. Badan Penerbit Universitas Diponegoro, 2006.

[12] J. Roboth, "Analisis Work Family Conflict, Stres Kerja Dan Kinerja Wanita Berperan Ganda Pada Yayasan Compassion East Indonesia," J. Ris. BISNIS DAN Manaj., 2015.

[13] D. Goleman, "Emotional Intelligence, Kecerdasan Emosional Mengapa EI Lebih Penting daripada IQ," Jakata PT Gramedia Pustaka Utama, 2015.

[14] K. Rahayu, "Pengaruh Motivasi Kerja Terhadap Kinerja Pegawai pada Sekretariat Daerah Kabupaten Kutai Timur," Ekonomia, 2017. 